Borsook, H. \& Huffman, H. M. (1938). In The Chemistry of the Amino Acids and Proteins, p. 822. [C. L. A. Schmidt, editor.] Springfield, I1l.: Charles C. Thomas.

Breirem, K. (1939). Tierernährung, r1, 487.

Breirem, K. (1954). In Festschrift anlässlich des 100 jährigen Bestehens der Landwirtschaftlichen Versuchsstation Leipzig-Möckern. Vol. 2. 100 Fahre Möckern. Die Bewertung des Futterstoffe und andere Probleme der Tierernährung, p. 91. [K. Nehring, editor.] Berlin: Deutscher Bauernverlag.

James, A. T. \& Martin, A. J. P. (1952). Biochem. F. 50, 679.

Kellner, O. (I 9oo). Landw. VersSta. 53, I.

Marston, H. R. (1955). In Progress in the Physiology of Farm Animals, Vol. 2, p. 543. [J. Hammond, editor.] London: Butterworths Scientific Publications.

Phillipson, A. T. \& Cuthbertson, D. P. (1956). Int. Congr. Anim. Husb. vir. Madrid, 6, 7.

Ritzman, E. G. \& Benedict, F. G. (1938). Publ. Carneg. Instn, no. 494.

Werner, A. \& Franke, E. R. (1953). In Festschrift anlässlich des 100 jährigen Bestehens der Landwirtschaftlichen Versuchsstation Leipzig-Möckern. Vol. 1. Untersuchungen über den Stärkewert verschiedener Futtermittel, p. 335. [K. Nehring \& A. Werner, editors.] Berlin: Deutscher Bauernverlag.

Wiegner, G. \& Grünigen, F. (1934). Arb. dtsch. Ges, Zücht. 63, I.

\title{
The amino-acid composition of potato protein and of cooked potato
}

\author{
By B. P. HUGHES* \\ Medical Research Council Department of Experimental Medicine, \\ University of Cambridge \\ (Received 7 September 1957)
}

The potato's nitrogenous constituents have a nutritive value as high as do those of whole wheat (Chick \& Cutting, I943). This has long seemed surprising, for the proportion of protein nitrogen in the potato may be as low as $37 \%$ and appears not to exceed about $60 \%$ (Neuberger \& Sanger, 1942; Mulder \& Bakema, 1956) of the total nitrogen. The non-protein nitrogen, which consists largely of asparagine and glutamine together with other nitrogenous bases (Neuberger \& Sanger, 1942), is of low nutritive value with no growth-promoting properties on its own (Chick \& Cutting, I943; Chick \& Slack, I949), but nevertheless appears to have a supplementary action when mixed with wheat gluten (Chick \& Slack, unpublished, reported by Chick, I950).

The existing amino-acid analyses of the heat-coagulable protein that forms the bulk of the potato protein (Neuberger \& Sanger, 1942; Mulder \& Bakema, 1956), of the non-protein nitrogen and of the whole raw potato have so far provided only in part an explanation of these facts; moreover, there are considerable discrepancies between the results of different authors.

For these reasons it seemed worth while to repeat and extend some of the analyses by the method of ion-exchange chromatography of Moore \& Stein (I951). The isolated, crude potato protein has been analysed and also the whole potato after being

* Present address: Institute of Neurology, The National Hospital, Queen Square, London, W.C. I. 
cooked by boiling, because this is how potatoes are generally prepared for consumption. Moreover, losses of nitrogenous material are likely to be greatest with this form of cooking (McCance, Widdowson \& Shackleton, 1936) and might cause differences in composition from that of whole raw potato, for which some information does exist (Slack, 1948; Lyman \& Kuiken, I949; Ågren, 1949).

\section{EXPERIMENTAL}

\section{Materials}

Potatoes, variety Epicure, grown in the Isle of Ely in $195^{6}$ were used throughout. The tubers had been held before use for 3 months in a commercial cold store at $4^{\circ}$.

Potato protein. The crude heat-coagulable potato protein was prepared by a procedure that combines some features of the methods described either by Chick \& Slack (1949) or by Mulder \& Bakema (1956). The expressed juice from whole raw potatoes minced with the addition of a small quantity of $\mathrm{NaHSO}_{3}$ and $\mathrm{NaCl}$ was diluted with its own volume of distilled water. After centrifugation to remove suspended matter, the slightly cloudy supernatant fluid was heated with constant stirring to $80-90^{\circ}$ for I $\mathrm{h}$ and the coagulated protein allowed to settle. Most of the supernatant fluid was poured off and the protein was separated by centrifuging and washed twice with dilute $(0.5 \%, v / v)$ acetic acid and then twice with absolute ethanol. The solvent was removed at room temperature under reduced pressure, and the product powdered. The powder was almost pure white in colour.

Raw potato. Peeled tubers of representative size $(60-250 \mathrm{~g})$ were homogenized with an equal weight of water.

Cooked potato. Peeled tubers of similar size to those used to prepare the raw-potato homogenate were boiled for $25 \mathrm{~min}$ by the usual domestic method with about $2 \mathrm{ml}$. water/g tuber. The drained cooked potatoes were homogenized with an equal weight of water.

The homogenates were sampled immediately for the determination of moisture, total nitrogen, protein and non-protein nitrogen, but the cooked potato for amino-acid estimations was stored at $-20^{\circ}$ until required.

\section{Methods}

Moisture was determined by drying to constant weight in air at $105^{\circ}$. Nitrogen determinations were carried out by a micro-Kjeldahl procedure with the seleniumdigestion catalyst of Chibnall, Rees \& Williams (1943).

The nitrogen in the potato homogenates was fractionated into protein and nonprotein nitrogen with ethanol by the method of Thompson \& Steward (1952) and the nitrogen in each fraction was separately determined. The total nitrogen in the homogenates was also determined, and the value agreed with that calculated from the sum of the protein and non-protein nitrogen.

From the analyses of the homogenates the moisture and the total nitrogen and protein nitrogen calculated as percentage of total nitrogen in the raw and cooked potato, were estimated. 
Hydrolysis of potato protein and cooked potato for estimation of amino-acids, except cystine and tryptophan, was carried out by refluxing the samples with $6 \mathrm{~N}-\mathrm{HCl}$, as described by Schram, Dustin, Moore \& Bigwood (1953).

Estimation of these amino-acids was performed by a photometric ninhydrin method, similar to that described by Yemm \& Cocking (I955), after separation by ion-exchange chromatography on a $150 \mathrm{~cm}$ column of the sulphonated polystyrene resin Zeo Karb 225 (nominally $4.5 \%$ cross-linkage, screened wet through a 300 -mesh sieve), by the gradient-elution method of Moore \& Stein (I954).

Cystine was determined as cysteic acid on both potato protein and cooked potato after treatment of the sample with performic acid and hydrolysis with $6 \mathrm{~N}-\mathrm{HCl}$ (Schram, Moore \& Bigwood, I954).

Tryptophan was estimated by the method of Graham, Smith, Hier \& Klein (1947), but measurements of the colour produced by the reaction of tryptophan with $p$-dimethylaminobenzaldehyde were carried out at a wavelength of $600 \mathrm{~m} \mu$, rather than $55^{\circ} \mathrm{m} \mu$, as this was found to correspond to the wavelength of maximum optical density. Spies \& Chambers (1949), using somewhat different reaction conditions, reported a similar absorption maximum.

\section{RESULTS}

\section{Moisture and nitrogen}

The percentages of moisture and nitrogen in potato protein, and in raw and cooked peeled potato are given in Table I. The moisture and nitrogen contents of the potato protein were similar to those found by other authors (Groot, 1945; Chick \& Slack, I949; Mulder \& Bakema, I956). The moisture content of the raw potato was high, the same as that of the cooked potato, which, however, may have been due to an unusually wet growing season in $195^{6}$.

Table I. Moisture and nitrogen content of potato preparations

$\begin{array}{lccc}\text { Material } & \begin{array}{c}\text { Nitrogen } \\ \text { Moisture }\end{array} & \begin{array}{c}\text { Protein nitrogen } \\ \text { (as percentage } \\ \text { of dry weight) }\end{array} & \begin{array}{c}\text { of total) } \\ \text { of tontage }\end{array} \\ \text { Raw, peeled potato } & 8 \% & \mathbf{I} \cdot 9 & 34 \\ \text { Boiled, peeled potato } & 83 & \mathbf{I} \cdot 8 & 37 \\ \text { Potato protein } & 7 \cdot 4 & \mathbf{I 5 \cdot 2} & -\end{array}$

The percentage of protein nitrogen found in the raw, peeled potato, $34 \%$ of the total nitrogen, was lower than the lowest value reported for the whole tuber by Neuberger \& Sanger (1942). However, the protein nitrogen of the whole tuber includes the relatively small amount of insoluble nitrogen assumed to be protein nitrogen and largely confined to the peel and outer layers of the cortex. My tubers were peeled as for cooking, so that a large part of the insoluble nitrogenous material was removed. Neuberger \& Sanger (1942) report a value as low as $28 \%$ for the proportion of protein nitrogen in the total soluble nitrogen; my result is therefore not exceptional. 


\section{Composition of potato protein}

Table 2 gives the amino-acid composition of potato protein, expressed as g aminoacid/I $6 \mathrm{~g}$ total nitrogen, obtained by analysis of hydrolysates. Except for cystine and tryptophan, which were estimated by other methods, different periods of hydrolysis, i.e. 24,48 and $96 \mathrm{~h}$, were used for estimating the destruction of certain labile aminoacids during hydrolysis. Losses of methionine, serine, threonine and, to a lesser extent, arginine were observed. The amounts of these amino-acids plotted against time of hydrolysis gave straight lines that could be extrapolated to zero time of hydrolysis. The extrapolated value is a more accurate estimate of the amount of a labile aminoacid in the protein (Smith, Stockell \& Kimmel, 1954) than a value derived from only one period of hydrolysis. The other amino-acids gave values independent, within experimental error, of times of hydrolysis.

Table 2. Amino-acid composition of potato fractions

\begin{tabular}{|c|c|c|c|c|}
\hline Amino-acid & $\begin{array}{l}\text { Potato } \\
\text { protein }\end{array}$ & $\begin{array}{l}\text { Boiled } \\
\text { peeled } \\
\text { potato }\end{array}$ & $\begin{array}{l}\text { Non-protein } \\
\text { nitrogen* }\end{array}$ & $\begin{array}{l}\text { Whole } \\
\text { wheat } \dagger\end{array}$ \\
\hline Arginine & $5.5 t$ & $4 \cdot 6$ & $4 \cdot I(2 \cdot 4-5 \cdot 4)$ & $4 \cdot 2$ \\
\hline Histidine & $2 \cdot 4$ & $I \cdot 8$ & $I \cdot 4(0.6-I .9)$ & $2 \cdot 2$ \\
\hline Isoleucine & $6 \cdot 8$ & $2 \cdot 4$ & $0.5)(1.6-3.3)$ & 34 \\
\hline Leucine & $I I \cdot I$ & 3.7 & $0\}$ & 6.5 \\
\hline Lysine & $8 \cdot 3$ & 4.8 & $2.7(\operatorname{tr},-1 \cdot 0)$ & $2 \cdot 6$ \\
\hline Phenylalanine & $6 \cdot 2$ & $3 \cdot 4$ & $1 \cdot 7(1 \cdot 0-2 \cdot 3)$ & $4 \cdot 8$ \\
\hline Methionine & $2 \cdot 8 \ddagger$ & $I \cdot 3$ & $0.5($ tr. -1.9$)$ & $\mathrm{I} \cdot 7$ \\
\hline Threonine & $5 \cdot 7 \ddagger$ & $3 \cdot 2$ & $I \cdot 7(0.5-1 \cdot 7)$ & 3.0 \\
\hline Tryptophan & $1 \cdot 8$ & $I \cdot I$ & 0.7 & - \\
\hline Valine & $8 \cdot 0$ & $4 \cdot I$ & $I \cdot 7(I \cdot 5-4 \cdot 1)$ & $3 \cdot 8$ \\
\hline Alanine & $4 \cdot 7$ & $2 \cdot 4$ & $I \cdot I(0.6-I \cdot 2)$ & $3 \cdot 4$ \\
\hline Aspartic acid & 13.0 & $22 \cdot 7$ & $28 \cdot 4$ & $4 \cdot 8$ \\
\hline Cystine & $1 \cdot 6$ & $1 \cdot 0$ & $0.6(\mathrm{tr} .-0.7)$ & - \\
\hline Glutamic acid & $I I \cdot 3$ & $23 \cdot 8$ & $3 I \cdot I$ & $28 \cdot 2$ \\
\hline Glycine & 4.9 & $1 \cdot 9$ & $0.2($ tr. $-\mathrm{I} \cdot 0)$ & 3.9 \\
\hline Proline & $5 \cdot 1$ & $2 \cdot 1$ & $0.3(\operatorname{tr} .-1 \cdot 7)$ & 10.4 \\
\hline Serine & $5.8 \ddagger$ & $2 \cdot 8$ & $I \cdot I(0 \cdot 6-I \cdot 6)$ & 4.6 \\
\hline Tyrosine & $6 \cdot 1$ & $3 \cdot 3$ & $1 \cdot 6(1 \cdot 2-5 \cdot 2)$ & $2 \cdot 9$ \\
\hline Ammonia & $1 \cdot 7$ & $4 \cdot 6$ & $6 \cdot 3$ & $2 \cdot 8$ \\
\hline$\gamma$-Aminobutyric acid & 0 & $I \cdot 3$ & $2 \cdot I(2 \cdot 0-8 \cdot 6)$ & - \\
\hline
\end{tabular}

tr. $=$ trace.

* Calculated (see p. 192). Figures in parentheses are the minimum and maximum values for raw potato found by Mulder \& Bakema (1956).

+ Nunnikhoven (1955).

$\ddagger$ Extrapolated to zero time of hydrolysis (see above).

The figures given in Table 2 represent the mean of the three determinations, except when the extrapolated value is quoted. The degrees of destruction of the labile aminoacids, estimated in this way for a $24 \mathrm{~h}$ hydrolysis, were for serine $9.4 \%$, for threonine $2.5 \%$, for arginine $\mathrm{I} \cdot 4 \%$ and for methionine $8.8 \%$. For serine and threonine these results agree well with those reported by Rees (1946). Recovery of the protein nitrogen as amino-acid nitrogen and ammonia averaged roo\%, a somewhat fortuitous result, as recoveries of individual amino-acids from known mixtures have an error of about 
$\pm 4 \%$. In Table 3 the present analysis is compared with analyses of potato protein carried out previously. There are considerable differences between the results of earlier workers, but when two or three of them agree their results are also similar to my results; in particular the total of isoleucine and of leucine is very similar to the total 'leucines' given by Slack (1948) and by Thompson \& Steward (1952). The values for tyrosine and proline, however, are higher than those obtained by quantitative paper chromatography (Thompson \& Steward, r952; Mulder \& Bakema, 1956).

Table 3. Comparison of the amino-acid composition of crude potato protein reported by various authors

\begin{tabular}{|c|c|c|c|c|c|}
\hline Amino-acid & This paper & $\begin{array}{c}\text { Thompson \& } \\
\text { Steward } \\
(1952)\end{array}$ & $\begin{array}{c}\text { Slack } \\
\text { (I948) }\end{array}$ & $\begin{array}{c}\text { Mulder \& } \\
\text { Bakema } \\
(1956)\end{array}$ & $\begin{array}{l}\text { Groot \& van } \\
\text { der Linden } \\
\quad(1949)\end{array}$ \\
\hline Arginine & $5 \cdot 5$ & 6.0 & 6.0 & $4 \cdot 3$ & - \\
\hline Histidine & $2 * 4$ & - & $2 \cdot 2$ & $2 \cdot 7$ & - \\
\hline $\begin{array}{l}\text { Isoleucine } \\
\text { Leucine }\end{array}$ & $\begin{array}{r}6 \cdot 8 \\
17.9\end{array}$ & $17 \cdot 6$ & $17 \cdot 5$ & $16 \cdot 5$ & 一 \\
\hline Lysine & $8 \cdot 3$ & $8 \cdot 0$ & 777 & $4 \cdot 2$ & $8 \cdot 3$ \\
\hline Phenylalanine & $6 \cdot 2$ & $12 \cdot 7$ & $6 \cdot 6$ & $5 \cdot 2$ & - \\
\hline Methionine & $2 \cdot 8$ & $I \cdot 5$ & $2 \cdot 3$ & $2 \cdot 4$ & - \\
\hline Threonine & $5 \cdot 7$ & $3 \cdot 2$ & $5 \cdot 9$ & $6 \cdot 2$ & - \\
\hline Valine & $8 \cdot 0$ & 7.7 & $6 \cdot 1$ & 6.7 & - \\
\hline Tryptophan & $\mathrm{I} \cdot 8$ & - & $I \cdot 6$ & $I \cdot 9$ & - \\
\hline Alanine & $4 \% 7$ & $6 \cdot 2$ & - & $5^{\circ} \mathrm{O}$ & - \\
\hline Aspartic acid & $13 \cdot 0$ & $12 \cdot 0$ & - & 9.5 & 一 \\
\hline Cystine & 1.6 & - & $2 \cdot 1$ & 0.9 & - \\
\hline Glutamic acid & II $\cdot 3$ & $14 \cdot 6$ & 一 & 9.7 & - \\
\hline Glycine & $4 \cdot 9$ & $5 \cdot 6$ & - & $5 \cdot 5$ & - \\
\hline Proline & $5 \cdot I$ & $3 \cdot 5$ & 一 & $4^{\circ} \circ$ & - \\
\hline Serine & $5 \cdot 8$ & 3.7 & - & 6.2 & - \\
\hline Tyrosine & $6 \cdot I$ & 3.9 & - & 4.5 & - \\
\hline Ammonia & $1 \cdot 7$ & - & - & $1 \cdot 6$ & - \\
\hline
\end{tabular}

\section{Composition of boiled peeled potato}

The amino-acid composition of boiled peeled potato is shown in Table 2 . On account of the presence of large amounts of carbohydrate, agreement between replicate determinations of the labile amino-acids in the whole potato was less satisfactory than between those with the relatively pure protein. Correction for hydrolytic losses by the method used for the latter was not considered satisfactory without a large number of determinations. Moreover, with methionine such a correction would be further complicated by the fact that methionine in the presence of carbohydrate is converted to a somewhat variable extent into methionine sulphoxide (Schram et al. 1953). The figures given represent the mean of three analyses carried out on potato hydrolysed for $24 \mathrm{~h}$. The value for methionine is the total of methionine and methionine sulphoxide, the latter calculated as methionine. For these reasons the results for methionine, serine and threonine may be somewhat low. Besides the eighteen common amino-acids, potato also contains $\gamma$-aminobutyric acid. Recovery from boiled potato of nitrogen, as amino-acid nitrogen and ammonia, averaged $95 \%$.

From the analytical results for cooked potato, potato protein and the ratio of 
protein to non-protein nitrogen it is possible to calculate approximately the composition of the non-protein nitrogen of the cooked potato, which is also given in Table 2. The concentrations of most of the amino-acids fall within the range found by Mulder \& Bakema (1956) by direct analyses of the non-protein nitrogen of raw potato (see Table 2), but there are some differences. These authors, in agreement with Neuberger \& Sanger (1942), found little lysine. However, Chick \& Slack (1949) found an appreciable amount of this amino-acid, i.e. $\mathrm{I}^{\circ} 9 \mathrm{~g} / \mathrm{r} 6 \mathrm{~g} \mathrm{~N}$, but not as much as I did. Mulder \& Bakema (1956), Neuberger \& Sanger (1942) and also Chick \& Slack (1949) found that a leucine-isoleucine fraction could be separated from the non-protein nitrogen. From optical-rotation measurements, Neuberger \& Sanger (1942) concluded that little isoleucine was present and that the leucine-isoleucine fraction therefore consisted mainly of leucine. From my analyses the amount of leucine in boiled potato is slightly less than would be expected even if the non-protein nitrogen were devoid of leucine, which probably indicates that leucine is almost absent from the non-protein nitrogen of the potatoes analysed, the apparent destruction merely reflecting the approximate nature of the calculation. The calculated amount of isoleucine in the non-protein nitrogen is also small. The values for aspartic and glutamic acid in the non-protein nitrogen of cooked potato cannot be directly compared with those for raw potato because they include the amounts derived from asparagine and glutamine, which would yield ammonia and the free acids during hydrolysis. The considerable amount of ammonia present in the hydrolysate indicates that much of the glutamic and aspartic acids was originally present as the amide.

Table 4 compares my values for boiled potato with those previously published for whole raw potato. The values in the literature for several amino-acids are not very consistent and on the whole they agree with the values for boiled potato about as well as they do with each other.

\section{DISCUSSION}

The high nutritive value of potato protein can be understood when its composition is compared with that of whole wheat (Table 2). Apart from histidine, it contains substantially more of all the essential amino-acids; this superiority is particularly striking for lysine, the amount present being similar to that in a typical animal protein. In agreement with the values for raw potato reported by Mulder \& Bakema (1956), the non-protein nitrogen of the cooked potato appears on the whole to be relatively poor in the essential amino-acids, but in this instance contained appreciable quantities of arginine and lysine (Table 2). However, such a large fraction of potato nitrogen is non-protein nitrogen that its contribution to the total amounts of the individual amino-acids cannot be altogether neglected, and it may therefore have a considerable effect on the nutritive value of the whole potato, which is likely to vary according to its exact composition.

Chick (1950) has reported a marked supplementary relation between wheat gluten and potato non-protein nitrogen in promoting the growth of rats. Although the data for raw potato indicate large variations between samples (Neuberger \& Sanger, 1942; Chick \& Slack, 1949; Mulder \& Bakema, 1956), my calculations suggest that the 
non-protein nitrogen may sometimes contain as much lysine as whole wheat, and hence considerably more than isolated gluten, which contains $\mathrm{I} \cdot 6 \mathrm{~g}$ lysine/ $\mathrm{i} 6 \mathrm{~g} \mathrm{~N}$ (Pence, Mecham, Elder, Lewis, Snell \& Olcott, 1950). A part at least of this supplementary action could therefore be explained if the non-protein nitrogen used in the experiment happened to be rich in lysine. However, an examination of the amino-acid composition of any non-protein nitrogen used in relation to its observed supplementary effect would be necessary to decide this point.

Table 4. Comparison of the amino-acid composition of boiled potato with published analyses of raw potato

(g amino-acid/16 $\mathrm{g} \mathrm{N}$ )

\begin{tabular}{|c|c|c|c|c|}
\hline \multirow[b]{2}{*}{ Amino-acid } & \multirow[b]{2}{*}{$\begin{array}{l}\text { Boiled } \\
\text { potato }\end{array}$} & \\
\hline & & $\begin{array}{c}\text { Lyman \& } \\
\text { Kuiken } \\
\text { (1949) }\end{array}$ & $\begin{array}{c}\text { Chick \& } \\
\text { Slack } \\
(1949)^{*}\end{array}$ & $\begin{array}{c}\text { Ágren } \\
\text { (r949) }\end{array}$ \\
\hline Arginine & $4 \cdot 6$ & $5 \cdot 3$ & $3 \cdot 2$ & $7 \cdot I$ \\
\hline Histidine & $\mathrm{I} \cdot 8$ & $I \cdot 4$ & $\mathrm{x} \cdot 5$ & $I \cdot 2$ \\
\hline Isoleucine & $2 \cdot 8$ & $3.7)$ & & $\{5 \cdot 9$ \\
\hline Leucine & $3 \cdot 7$ & $4 \cdot 6\}$ & $9 \cdot 2$ & $\left\{\begin{array}{l}4 \cdot 6 \\
4 \cdot 6\end{array}\right.$ \\
\hline Lysine & $4 \cdot 8$ & $5 \cdot 1$ & $4 \cdot 0$ & 3.7 \\
\hline Phenylalanine & $3 \cdot 4$ & $3 \cdot 1$ & $5 \cdot 0$ & $3 \cdot 6$ \\
\hline Methionine & $I \cdot 3$ & $I \cdot 5$ & $1 \cdot 3$ & $2 \cdot 5$ \\
\hline Threonine & $3 \cdot 2$ & $2 \cdot 5$ & $2 \cdot 9$ & 2.5 \\
\hline Tryptophan & $I \cdot I$ & $I \cdot 8$ & 0.6 & $I \cdot O$ \\
\hline Valine & $4 \cdot I$ & $4 \cdot 8$ & $4 \cdot 4$ & $4 \cdot 3$ \\
\hline Alanine & $2 \cdot 4$ & - & - & $6 \cdot 1$ \\
\hline Aspartic acid & $22 \cdot 7$ & - & - & I I 5 \\
\hline Cystine & $1 \cdot 0$ & - & $I \cdot 5$ & 0.6 \\
\hline Glutamic acid & $23 \cdot 8$ & - & - & $7 \cdot 4$ \\
\hline Glycine & $I \cdot 9$ & - & - & $I \cdot 9$ \\
\hline Proline & $2 \cdot I$ & - & 一 & 3.0 \\
\hline Serine & $2 \cdot 8$ & - & - & $2 \cdot 6$ \\
\hline Tyrosine & $3 \cdot 3$ & - & - & $2 \cdot 5$ \\
\hline Ammonia & $4 \cdot 6$ & - & - & $3 \cdot 8 \uparrow$ \\
\hline$\gamma$-Aminobutyric acid & $I \cdot 3$ & - & - & - \\
\hline
\end{tabular}

* Recalculated to compute the composition of a potato with protein nitrogen amounting to $37 \%$ of total nitrogen.

$\uparrow$ Recalculated from ammonia $\mathrm{N}$ as percentage of total $\mathrm{N}$.

In compiling for practical use, for example in tables of food composition, amino-acid figures for the potato, considerable difficulties arise because of possible differences between samples. Wide variations can occur in the total nitrogen content, in the proportion of protein to non-protein nitrogen (Salaman, I926; Neuberger \& Sanger, 1942; Mulder \& Bakema, 1956) and in the composition of the non-protein fraction itself (Mulder \& Bakema, I956). The considerable discrepancies between the published analyses of raw potato (Slack, I948; Lyman \& Kuiken, 1949; Ågren, 1949) can in most instances be ascribed to possible differences in the material analysed, apart from differences in analytical technique. My analyses of boiled potato show that within these rather wide limits of possible variation its composition is similar to that of raw potato. Likewise the non-protein nitrogen fraction of boiled potato is similar in composition to that of the raw potato.

To take account accurately of all possible differences between potato samples 
requires a complete amino-acid analysis on each sample, which is usually impracticable. However, if, for example, we need to know the contribution of potatoes to the total amino-acid intake from a particular diet, then we can at least obtain a minimum value if the total nitrogen and the ratio of protein to non-protein nitrogen of the sample is known, since the composition of the protein appears to be largely independent of variety and conditions of growth (Mulder \& Bakema, 1956).

\section{SUMMARY}

I. The amino-acid composition of potato protein and of boiled, peeled potato has been determined by ion-exchange chromatography, but tryptophan was determined by a separate chemical method.

2. The nitrogen of potato protein was a much better source of the essential amino-acids than that of cooked potato.

3. From these results and the value for the protein nitrogen, expressed as a percentage of total nitrogen in the potatoes analysed, the approximate amino-acid composition of the non-protein nitrogen of boiled potato was calculated. It was poor in most of the essential amino-acids, but contained appreciable amounts of lysine and arginine.

4. The results are compared with those found previously for potato protein and for raw potato by other workers, and their nutritive significance is discussed.

The author wishes to thank Dame Harriette Chick for kindly reading and criticizing his manuscript before its submission for publication.

\section{REFERENCES}

Agren, G. (1949). Acta chem. scand. 3, 93 I.

Chibnall, A. C., Rees, M. W. \& Williams, E. F. (1943). Biochem. F. 37, 354.

Chick, H. (1950). F. Amer. med. Wom. Ass. 5, 435.

Chick, H. \& Cutting, M. E. M. (I943). Lancet, 245, 667.

Chick, H. \& Slack, E. B. (1949). Biochem. F. 45, 21 I.

Graham, C. E., Smith, E. P., Hier, S. W. \& Klein, D. (1947). F. biol. Chem. 168, 7 I 1 .

Groot, E. H. (1945). Voeding, 6, I53.

Groot, E. H. \& van der Linden, A. C. (1949). Voeding, ro, 18.

Lyman, C. M. \& Kuiken, K. A. (1949). Bull. Tex. agric. Exp. Sta. no. 708.

McCance, R. A., Widdowson, E. M. \& Shackleton, L. R. B. (1936). Spec. Rep. Ser. med. Res. Coun., Lond., no. 213.

Moore, S. \& Stein, W. H. (1951). F. biol. Chem. r92, $66_{3}$.

Moore, S. \& Stein, W. H. (1954). F. biol. Chem. 211, 893 .

Mulder, E. G. \& Bakema, K. (1956). Plant and Soil, 7, I35.

Neuberger, A. \& Sanger, F. (1942). Biochem. F. 36, 662 .

Nunnikhoven, R. (1955). De aminozuur-samenstelling van tarwe-eiwitten in verband met de uitmalingsgraad alsmede de instrumentatie voor kolom-chromatografie. Thesis, University of Amsterdam.

Pence, J. W., Mecham, D. K., Elder, A. H., Lewis, J. C., Snel1, N. S. \& Olcott, H. S. (r950). Cereal Chem. 27, 335 .

Rees, M. W. (1946). Biochem. F. 40, 632.

Salaman, R. N. (1926). Potato Varieties. Cambridge University Press.

Schram, E., Dustin, J. P., Moore, S. \& Bigwood, E. J. (1953). Analyt. chim. acta, 9, 149.

Schram, E., Moore, S. \& Bigwood, E. J. (1954). Biochem. F. 57, 33.

Slack, E. B. (1948). Nature, Lond., I6r, 2 I 1.

Smith, E. L., Stockell, A. \& Kimmel, J. R. (1954). F. biol. Chem. 207, 55 I.

Spies, J. R. \& Chambers, D. C. (I949). Analyt. Chem. 21, 1249.

Thompson, E. W. \& Steward, F. C. (1952). F. exp. Bot. 3, 170.

Yemm, E. W. \& Cocking, E. C. (I955). Analyst, 8o, 209. 